\title{
Profil pemecahan masalah persamaan garis lurus siswa SMP berdasarkan jenis kelamin
}

\author{
Zainuddin, Zainal Abidin, Susanti $^{1}$
}

\begin{abstract}
Abstrak: Hasil tes internasional seperti PISA dan TIMSS menunjukkan rendahnya kemampuan pemecahan masalah matematika siswa Indonesia. Penelitian ini bertujuan mendeskripsikan profil pemecahan masalah persamaan garis (PGL) lurus siswa SMP berdasarkan jenis kelamin. Penelitian ini menggunakan pendekatan kualitatif dengan jenis eksploratif. Data dikumpulkan melalui lembar tugas pemecahan masalah persamaan garis lurus, wawancara, dan rekaman audio visual. Data dianalisis secara deskriptif melalui reduksi data, penyajian data, dan penarikan kesimpulan. Penelitian ini menemukan bahwa subjek laki-laki dan perempuan mengidentifikasi masalah dengan membaca berkali-kali soal tanpa suara dan mampu menceritakan kembali soal yang telah dibacakan menggunakan bahasa sendiri sambil melihat teks. Pada tahap merencanakan penyelesaian masalah, subjek laki-laki dan perempuan sudah dapat menuliskan apa yang diketahui ditanya dan mengubah bentuk soal cerita menjadi model matematika. Pada tahap melaksanakan rencana penyelesaian masalah, subjek laki-laki dan perempuan masih keliru dalam menggunakan rumus atau konsep matematika. Dan pada tahap pengecekan kembali, subjek laki-laki dan perempuan melakukan pengecekan kembali terhadap hasil penyelesaian. Penelitian ini menyimpulkan bahwa subjek laki dan perempuan dengan kemampuan matematika tinggi memiliki profil yang tidak berbeda dalam menyelesaikan masalah PGL.
\end{abstract}

Kata kunci: Pemecahan Masalah; Persamaan Garis Lurus; Jenis Kelamin

\begin{abstract}
International assessment program like PISA and TIMSS showed that Indonesia students have low problem solving ability on mathematics. The purpose of this research was to describe and analyze the profile of grade 7 students' problem solving based on the gender. The research used qualitative explorative approach. The data was collected through problem-solving task regarding line equation, interview, and audio-visual recording then it was analyzed descriptively by reducing data, presenting data, and drawing the conclusion. The research found that both male and female subject
\end{abstract}

\footnotetext{
${ }^{1}$ Universitas Islam Negeri (UIN) Ar-raniry Banda Aceh, Banda Aceh, Indonesia, zainuddinelmanaf@gmail.com
} 
identified problems by reading the questions many times soundlessly and were able to retell the questions which had been read using their languages while looking at the text. At the stage of problem solving plan, both male and female subject were able to write down what is known and asked and change the mathematics problems into the mathematics model. At the stage of applying problem solving plan, both male and female had inproperly used the concept or rules. At the stage of rechecking the problem solving, both subjects did recheck the problems solved. The research concludes that male and female student with high mathematics ability have similar profile in solving mathematics problems.

Keywords: Problem Solving; Line Equation; Gender

\section{A. Pendahuluan}

Tujuan pembelajaran matematika di SMP adalah siswa dapat memahami konsep matematika, menjelaskan koneksi antar konsep dan mengaplikasikan konsep atau logaritma secara luwes, akurat, efesien dan tepat dalam pemecahan masalah. Siswa diharapkan dapat memecahkan masalah yang meliputi kemampuan memahami masalah, merancang model, dan menafsirkan solusi yang diperoleh (Permendiknas RI Nomor 22, 2006). Hal tersebut menandakan bahwa siswa dituntut tidak hanya terampil dalam menyelesaikan soal-soal yang diberikan oleh guru tetapi juga terampil mencari solusi terhadap sebuah permasalahan matematika.

Berdasarkan hasil PISA (OECD, 2013, 2016), kemampuan literasi matematika siswa Indonesia masih jauh di bawah rata-rata negara OECD. Hasil PISA tersebut menunjukkan bahwa kebanyakan siswa Indonesia belum mampu menyelesaikan soal pemecahan masalah yang membutuhkan aplikasi dan analisis. Hasil TIMSS juga melaporkan bahwa siswa Indonesia berada pada posisi 38 dari 42 negara yang mengikuti olimpiade matematika di Boston (Mullis, Martin, Foy, \& Arora, 2012). Selain itu hasil penelitian Azhari (2011) menunjukkan bahwa siswa belum mampu dan mengalami kesulitan dalam menyelesaikan soal-soal matematika tingkat tinggi. Dalam hal ini, siswa hanya mampu menyelesaikan soal dalam bentuk prosedural menggunakan rumus.

Penelitian yang dilakukan oleh Tanjungsari, Soedjoko, dan Mashuri (2012) menemukan empat jenis kesulitan yang dialami oleh siswa dalam memahami persamaan garis lurus yaitu kesulitan siswa dalam kemampuan menerjemahkan, kesulitan dalam menggunakan prinsip, kesulitan dalam menggunakan konsep, dan kesulitan dalam kemampuan 
algoritma. Kesulitan-kesulitan tersebut tidak mendukung siswa dalam pemecahan masalah. Kesulitan melakukan pemecahan masalah juga bisa disebabkan oleh faktor-faktor lain seperti faktor psikologis. Aminah dan Wulandari (2011) menjelaskan bahwa siswa perempuan lebih tertarik pada masalah-masalah kehidupan yang nyata sedangkan laki-laki lebih tertarik pada hal abstrak.

Untuk mengatasi kesulitan siswa dalam pemecahan masalah matematika, seorang guru perlu mengetahui profil pemecahan masalah siswa untuk suatu materi tertentu misalnya persamaan garis lurus sehingga guru dapat menemukan acuan pembelajaran yang tepat. Melalui acuan pembelajaran yang ditemukan tersebut, guru dapat merancang pembelajaran berbasis pemecahan masalah untuk siswa yang memiliki kemampuan pemecahan masalah matematika yang sama, baik itu siswa laki-laki atau perempuan. Kemampuan pemecahan masalah matematika merupakan salah satu kemampuan yang penting untuk dimiliki oleh setiap siswa karena merupakan tahapan akhir belajar matematika. Krulik dan Rudnick (1996) menegaskan bahwa pemecahan masalah matematika dapat dilakukan oleh siswa setelah memiliki pengetahuan, keterampilan serta pemahaman.

Hudoyo dan Sutawijaya (1998) membagi masalah matematika ke dalam beberapa jenis yaitu masalah translasi, masalah aplikasi, masalah proses, dan masalah teka-teki. Menurut Polya (1973), pemecahan masalah matematika dapat diselesaikan melalui memahami masalah, membuat rencana pemecahan masalah, melaksanakan rencana pemecahan masalah, dan memeriksa kembali hasil penyelesaian. Penggunaan langkah-langkah pemecahan masalah Polya mampu meningkatkan kemampuan siswa untuk menganalisis dan memahami suatu masalah, membuat rencana penyelesaian, dan kemudian menelaah kembali hasil pekerjaannya (Zaif, Sunardi, \& Diah, 2013).

Berdasarkan beberapa hal yang terkait dengan pembelajaran matematika yaitu siswa tidak hanya diharapkan dapat memiliki keterampilan menyelesaikan soal menggunakan rumus tetapi juga mampu melakukan pemecahan masalah (Permendiknas RI Nomor 22, 2006), faktor yang mempengaruhi siswa dalam pemecahan masalah (Aminah \& Wulandari, 2011; Krulik \& Rudnick, 1996), dan kesulitan siswa dalam memahami materi persamaan garis lurus (Tanjungsari, Soedjoko, \& Mashuri 2012), maka dipandang penting dilakukan penelitian untuk mengetahui profil pemecahan masalah siswa dalam menyelesaikan permasalahan persamaan garis. Penelitian ini bertujuan mendeskripsikan profil pemecahan masalah persamaan garis lurus siswa kelas 7 SMP berdasarkan jenis kelamin. 


\section{B. Metode Penelitian}

Subjek dalam penelitian ini adalah siswa kelas VIII pada SMPN 6 Banda Aceh sebanyak 2 orang (1 laki-laki dan 1 perempuan). Pemilihan subjek penelitian didasarkan pada kemampuan siswa dalam komunikasi karena peneliti membutuhkan informasi yang disampaikan secara lisan berupa gagasan, ide, maupun alasan. Subjek penelitian ini juga dibatasi pada kemampuan matematika tinggi karena penelitian fokus mendeskripsikan profil pemecahan masalah siswa laki-laki dan perempuan. Klasifikasi kemampuan matematika ditentukan melalui pemberian 5 soal matematika dalam bentuk uraian yang dimodifikasi dari soal pilihan ganda.

Dalam penelitian ini, peneliti merupakan instrumen utama. Sugiyono (2013) mengatakan bahwa segala sesuatu dalam penelitian kualitatif belum mempunyai bentuk yang pasti. Segala sesuatu masih perlu dikembangkan sepanjang penelitian itu, tidak ada pilihan lain dan hanya peneliti itu sendiri sebagai alat satu-satunya yang dapat mencapainya. Intrumen pendukung yang digunakan adalah soal tes kemampuan matematika, lembar tugas pemecahan masalah persamaan garis lurus (TPMPGL), pedoman wawancara, dan alat perekam. Intrumen tersebut telah melalui validasi ahli. Tes kemampuan matematika digunakan untuk memperoleh data tentang kemampuan matematika siswa berdasarkan jenis kelamin kemudian dipilih dua subjek yang memiliki kemampuan matematika tinggi. TPMPGL diberikan dua kali kepada kedua subjek untuk mengetahui konsistensi kemampuan pemecahan masalah pada materi persamaan garis lurus (PGL). Wawancara dilakukan untuk mengonfirmasi hasil kerja siswa pada TPMPGL dan mengetahui profil pemecahan masalah subjek penelitian. Indikator pemecahan masalah yang digunakan dalam penelitian ini dikembangkan dari langkah-langkah pemecahan masalah Polya (1973), yaitu memahami masalah, membuat rencana pemecahan masalah, melaksanakan rencana pemecahan masalah, dan memeriksa kembali hasil pemecahan masalah.

Teknik analisis data yang dilakukan dalam penelitian ini terdiri dari tiga tahapan yaitu reduksi data, penyajian data, dan penarikan kesimpulan. Hal Pada tahap reduksi, peneliti merangkum data yang dikumpulkan berkaitan dengan pemecahan masalah kemudian membuat kode TPMPGL (Tugas Pemecahan Masalah Persamaan Garis Lurus), P (Peneliti), SL (Subjek Laki-Laki), dan SP (Subjek Perempuan). Setelah direduksi, data dikelompokkan dan disajikan dalam bentuk teks yang bersifat naratif. Penarikan kesimpulan dalam penelitian ini mengacu pada indikator pemecahan masalah. Penarikan kesimpulan dilakukan untuk 
mengungkapkan profil siswa memecahkan masalah persamaan garis lurus berdasarkan jenis kelamin.

\section{Temuan dan Pembahasan}

Pada bagian ini, akan disajikan terlebih dahulu data hasil penelitian berdasarkan profil pemecahan masalah persamaan garis lurus subjek lakilaki dan perempuan. Masing-masing subjek diberikan 2 soal TPMPGL.

\section{Profil pemecahan masalah PGL SL}

\section{Memahami masalah}

Berdasarkan hasil kerja dan wawancara dengan SL, diperoleh deskripsi bagaimana SL memahami masalah pada TPMPGL 1 dan TPMPGL 2 pada Tabel 1.

Tabel 1. Deskripsi SL memahami masalah

\begin{tabular}{lll}
\hline $\begin{array}{c}\text { Nomor } \\
\text { Soal }\end{array}$ & \multicolumn{1}{c}{ TPMPGL 1 } & \multicolumn{1}{c}{ TPMPGL 2} \\
\hline & Membaca soal tanpa suara & Membaca soal tanpa suara \\
& sebanyak dua kali; & sebanyak dua kali; \\
& Menceritakan kembali soal yang & Menceritakan kembali soal \\
& telah dibacakan menggunakan & yang telah dibacakan \\
& bahasa sendiri sambil melihat & menggunakan bahasa sendiri \\
& teks serta mengubah cerita & sambil melihat teks serta \\
menjadi ilustrasi yang lain; & mengubah cerita menjadi \\
& Menentukan titik-titik koordinat & ilustrasi yang lain; \\
& yang belum diketahui di soal; & Menentukan titik-titik \\
& Menyebutkan yang diketahui & koordinat yang belum \\
dan ditanyakan pada soal & diketahui di soal; \\
dengan suara nyaring. & Menyebutkan yang diketahui \\
& & dan ditanyakan pada soal \\
& Membaca soal dengan tanpa & Membaca soal dengan tanpa \\
suara; & suara; \\
Menceritakan kembali soal yang & Menceritakan kembali soal \\
telah dibacakan menggunakan & yang telah dibacakan \\
bahasa sendiri sambil melihat & menggunakan bahasa sendiri \\
teks; & sambil melihat teks; \\
Menentukan sifat dari 2 & Mengetahui sifat dari 2 \\
persamaan garis yang saling & persamaan garis yang saling \\
sejajar; & tegak lurus; \\
Menyebutkan informasi yang & Menyebutkan informasi yang \\
diketahui dan ditanyakan. & diketahui dan ditanyakan. \\
\hline & &
\end{tabular}


Berdasarkan analisis data SL dalam memahami masalah, maka profil memahami masalah SL beserta indikatornya dapat dilihat pada Tabel 2 berikut.

Tabel 2. Profil memahami masalah SL

\begin{tabular}{llll}
\hline \multicolumn{1}{c}{ Indikator } & \multicolumn{1}{c}{ Tahap Memahami Masalah } & \\
\hline 1. & Siswa dapat & Membaca soal tanpa & Membaca soal \\
menentukan hal yang & suara sebanyak dua & dengan tanpa suara; \\
diketahui dalam soal & kali; & Menceritakan \\
persamaan garis lurus; & Menceritakan & kembali soal yang \\
2. & kembali soal yang & telah dibacakan \\
menentukan hal yang & telah dibacakan & menggunakan \\
ditanyakan dalam & menggunakan & bahasa sendiri \\
persamaan garis lurus; & bahasa sendiri sambil & sambil melihat teks; \\
Siswa dapat & melihat teks; & Mengidentifikasi \\
menceritakan kembali & Mengubah cerita & sifat dari 2 \\
soal persamaan garis & menjadi ilustrasi & persamaan garis. \\
lurus dengan & yang lain. & Menyebutkan \\
menggunakan bahasa & Mengidentifikasi & informasi yang \\
sendiri; & titik-titik koordinat & diketahui dan \\
Siswa dapat & yang belum diketahui & ditanyakan. \\
menentukan informasi & di soal; & \\
yang belum diketahui & Menyebutkan yang & \\
sebagai syarat perlu & diketahui dan & \\
penyelesaian soal & ditanyakan pada soal & \\
persamaan garis lurus & dengan suara & \\
jika diperlukan. & nyaring. & \\
\hline
\end{tabular}

2. Membuat rencana pemecahan masalah

Berdasarkan hasil kerja dan wawancara dengan SL, diperoleh deskripsi bagaimana SL membuat rencana pemecahan masalah pada TPMPGL 1 dan TPMPGL 2 pada Tabel 3.

Tabel 3. Deskripsi SL membuat rencana pemecahan masalah

\begin{tabular}{cll}
\hline $\begin{array}{c}\text { Nomor } \\
\text { Soal }\end{array}$ & \multicolumn{1}{c}{ TPMPGL 1 } & \multicolumn{1}{c}{ TPMPGL 2 } \\
\hline \multirow{4}{*}{1} & Subjek merencanakan & Subjek merencanakan \\
pemecahan masalah dengan & pemecahan masalah dengan \\
& menentukan rumus mencari & menentukan rumus mencari \\
& nilai gradien yaitu $m=\frac{\Delta y}{\Delta x}$ dan & nilai gardien yaitu $m=\frac{\Delta y}{\Delta x}$ dan \\
& rumus $y-y_{1}=m\left(x-x_{1}\right)$ & rumus $y-y_{1}=m\left(x-x_{1}\right)$ \\
\hline
\end{tabular}




\begin{tabular}{|c|c|c|}
\hline $\begin{array}{c}\text { Nomor } \\
\text { Soal }\end{array}$ & TPMPGL 1 & TPMPGL 2 \\
\hline & $\begin{array}{l}\text { untuk menentukan persamaan } \\
\text { garis kemudian } \\
\text { mengerjakannya; } \\
\text { Subjek hanya mengetahui satu } \\
\text { cara penyelesaian. }\end{array}$ & $\begin{array}{l}\text { untuk mencari persamaan } \\
\text { garis, kemudian } \\
\text { mengerjakannnya; } \\
\text { Subjek hanya mengetahui satu } \\
\text { cara penyelesaian. }\end{array}$ \\
\hline 2 & $\begin{array}{l}\text { Subjek merencanakan } \\
\text { pemecahan masalah dengan } \\
\text { menggunakan rumus } \\
y=m x+c \text { karena cara } \\
\text { tersebut lebih mudah; } \\
\text { Subjek mengatakan } \\
\text { menggunakan rumus } \\
m=-\left(\frac{a}{b}\right) \text { merupakan cara } \\
\text { yang kedua tetapi kurang } \\
\text { paham. }\end{array}$ & $\begin{array}{l}\text { Subjek membuat rencana } \\
\text { pemecahan masalah dengan } \\
\text { menentukan rumus } \\
y=m x+c \text { untuk } \\
\text { dihubungkan dengan sifat } \\
m_{1} x m_{2}=-1 \text {, kemudian } \\
\text { mengerjakannya; } \\
\text { Subjek merencanakan } \\
\text { pemecahan masalah dengan } \\
\text { satu cara penyelesaian karena } \\
\text { kurang paham dengan cara } \\
\text { yang lain. }\end{array}$ \\
\hline
\end{tabular}

Berdasarkan analisis data SL dalam membuat rencana pemecahan masalah maka profil membuat rencana pemecahan masalah SL beserta indikatornya dapat dilihat pada Tabel 4 berikut.

Tabel 4. Profil membuat rencana pemecahan masalah SL

\begin{tabular}{|c|c|c|}
\hline \multicolumn{3}{|c|}{ Tahap Membuat Rencana Pemecahan Masalah } \\
\hline Indikator & Deskripsi Soal 1 & Deskripsi Soal 2 \\
\hline $\begin{array}{l}\text { Siswa dapat } \\
\text { merencanakan } \\
\text { pemecahan masalah } \\
\text { persamaan garis lurus } \\
\text { sebagai pedoman } \\
\text { dalam penyelesaian } \\
\text { masalah berdasarkan } \\
\text { pemahaman siswa. }\end{array}$ & $\begin{array}{l}\text { Menentukan rumus } \\
\text { yang dianggap tepat } \\
\text { untuk mencari nilai } \\
\text { gradien dan } \\
\text { persamaan garis } \\
\text { kemudian } \\
\text { mengerjakannya; } \\
\text { Subjek hanya } \\
\text { mengetahui satu cara } \\
\text { penyelesaian. }\end{array}$ & $\begin{array}{l}\text { Mengubah bentuk } \\
\text { persamaan kedalam } \\
\text { bentuk fungsi eksplisit; } \\
\text { Menghubungkan nilai } \\
\text { gradien dengan sifat } 2 \\
\text { persamaan garis baik } \\
\text { yang saling sejajar } \\
\text { maupun saling tegak } \\
\text { lurus; } \\
\text { Subjek kurang memahami } \\
\text { cara penyelesaian yang } \\
\text { lain. }\end{array}$ \\
\hline
\end{tabular}


3. Melaksanakan rencana pemecahan masalah

Berdasarkan hasil kerja dan wawancara dengan SL, diperoleh deskripsi bagaimana SL melaksanakan rencana pemecahan masalah pada TPMPGL 1 dan TPMPGL 2 pada Tabel 5.

Tabel 5. Deskripsi SL melaksanakan rencana pemecahan masalah

\begin{tabular}{|c|c|c|}
\hline $\begin{array}{c}\text { Nomor } \\
\text { Soal }\end{array}$ & TPMPGL 1 & TPMPGL 2 \\
\hline 1 & $\begin{array}{l}\text { Subjek menggunakan rumus } \\
m=\frac{\Delta y}{\Delta x} \text { untuk mencari nilai } \\
\text { kemiringan dan rumus } \\
y-y_{1}=m\left(x-x_{1}\right) \text { untuk } \\
\text { menentukan persamaan garis; } \\
\text { Subjek menggunakan rumus- } \\
\text { rumus tersebut dengan tepat. }\end{array}$ & $\begin{array}{l}\text { Subjek menggunakan rumus } \\
m=\frac{\Delta y}{\Delta x} \text { untuk mencari nilai } \\
\text { kemiringan dan rumus } \\
y-y_{1}=m\left(x-x_{1}\right) \text { untuk } \\
\text { menentukan persamaan garis; } \\
\text { Subjek menggunakan rumus- } \\
\text { rumus tersebut dengan tepat. }\end{array}$ \\
\hline 2 & $\begin{array}{l}\text { Subjek mengubah persamaan } \\
\text { garis menjadi bentuk } \\
y=m x+c \text { untuk } \\
\text { memperoleh nilai gradien; } \\
\text { Menggunakan sifat } 2 \\
\text { persamaan garis yang sejajar } \\
\text { yaitu } m_{1}=m_{2} ; \\
\text { Subjek melakukan kesalahan } \\
\text { pada saat melakukan } \\
\text { penyederhanaan variabel. }\end{array}$ & $\begin{array}{l}\text { Subjek mengubah bentuk } \\
\text { persamaan garis menjadi } \\
\text { bentuk } y=m x+c \text {; } \\
\text { Menghubungkan dengan sifat } \\
2 \text { persamaan garis yang saling } \\
\text { tegak lurus yaitu } m_{1} x m_{2}= \\
-1 ; \\
\text { Subjek melakukan kesalahan } \\
\text { pada saat menyederhanakan } \\
\text { variabel dan tidak } \\
\text { menyelesaikan pertanyaan } \\
\text { yang kedua. }\end{array}$ \\
\hline
\end{tabular}

Berdasarkan analisis data SL dalam melaksanakan rencana pemecahan masalah maka profil melaksanakan rencana pemecahan masalah SL beserta indikatornya dapat dilihat Tabel 6 berikut.

Tabel 6. Profil melaksanakan rencana pemecahan masalah SL

Tahap Melaksanakan Rencana Pemecahan Masalah Indikator Deskripsi Soal 1 Deskripsi Soal 2

\begin{tabular}{lll}
\hline Siswa menuliskan & Subjek & Subjek melaksanakan \\
langkah-langkah & menggunakan & rencana pemecahan masalah \\
penyelesaian & rumus untuk & dengan mengubah bentuk \\
persamaan garis & mencari nilai & persamaan garis menjadi \\
lurus sesuai dengan & kemiringan dan & bentuk eksplisit; \\
yang direncanakan; & menentukan & Menghubungkan dengan \\
Siswa teliti dalam & persamaan garis; & sifat 2 persamaan garis yang \\
\hline
\end{tabular}




\begin{tabular}{lll}
\multicolumn{3}{c}{ Tahap Melaksanakan Rencana Pemecahan Masalah } \\
\multicolumn{1}{c}{ Indikator } & \multicolumn{1}{c}{ Deskripsi Soal 1 } & \multicolumn{1}{c}{ Deskripsi Soal 2 } \\
\hline menyelesaikan soal & Subjek & saling sejajar atau tegak \\
pemecahan & menggunakan & lurus; \\
persamaan garis & rumus-rumus & Subjek melakukan kesalahan \\
lurus. & tersebut dengan & pada saat menyederhanakan \\
& tepat. & variabel. \\
\hline
\end{tabular}

4. Pengecekan kembali hasil pemecahan masalah

Berdasarkan hasil kerja dan wawancara dengan SL, diperoleh deskripsi bagaimana SL mengecek kembali hasil pemecahan masalah pada TPMPGL 1 dan TPMPGL 2 pada Tabel 7.

Tabel 7. Deskripsi SL mengecek kembali hasil pemecahan masalah

\begin{tabular}{cll}
\hline $\begin{array}{c}\text { Nomor } \\
\text { Soal }\end{array}$ & \multicolumn{1}{c}{ TPMPGL 1 } & \multicolumn{1}{c}{ TPMPGL 2 } \\
\hline \multirow{2}{*}{1} & $\begin{array}{l}\text { Subjek memeriksa kembali } \\
\text { hasil penyelesaian minimal } 1 \\
\text { kali meskipun sudah yakin } \\
\text { jawabannya benar. }\end{array}$ & $\begin{array}{l}\text { Subjek memeriksa kembali hasil } \\
\text { penyelesaian sebanyak 1 kali } \\
\text { karena belum yakin jawabannya } \\
\text { benar. }\end{array}$ \\
\hline \multirow{2}{*}{$\begin{array}{l}\text { Tidak memeriksa kembali } \\
\text { hasil penyelesaian meskipun } \\
\text { belum yakin jawabannya } \\
\text { benar. }\end{array}$} & $\begin{array}{l}\text { Tidak memeriksa kembali hasil } \\
\text { penyelesaian meskipun belum } \\
\text { yakin jawabannya benar. }\end{array}$ \\
\hline
\end{tabular}

Berdasarkan analisis data SL dalam memeriksa kembali hasil penyelesaian maka profil memeriksa kembali hasil peyelesaian SL beserta indikatornya dapat dilihat pada Tabel 8 berikut.

Tabel 8. Profil memeriksa kembali hasil penyelesaian SL

\begin{tabular}{|c|c|c|}
\hline \multicolumn{3}{|c|}{ Tahap Memeriksa Kembali Hasil Penyelesaian } \\
\hline Indikator & Deskripsi Soal 1 & Deskripsi Soal 2 \\
\hline $\begin{array}{l}\text { Siswa melakukan } \\
\text { pemeriksaan soal } \\
\text { pemecahan } \\
\text { masalah } \\
\text { persamaan garis } \\
\text { lurus }\end{array}$ & $\begin{array}{l}\text { Subjek } \\
\text { kembali } \\
\text { penyelesaian minimal } 1 \\
\text { kali meskipun sudah } \\
\text { yakin jawabannya benar. }\end{array}$ & $\begin{array}{l}\text { Tidak memeriksa kembali } \\
\text { hasil penyelesaian } \\
\text { meskipun belum yakin } \\
\text { jawabannya benar. }\end{array}$ \\
\hline
\end{tabular}




\section{Profil pemecahan masalah PGL SP}

1. Tahap memahami masalah

Berdasarkan hasil kerja dan wawancara dengan SP, diperoleh deskripsi bagaimana SP memahami masalah pada TPMPGL 1 dan TPMPGL 2 pada Tabel 9.

Tabel 9. Deskripsi SP memahami masalah

\begin{tabular}{|c|c|c|}
\hline $\begin{array}{c}\text { Nomor } \\
\text { Soal }\end{array}$ & TPMPGL 1 & TPMPGL 2 \\
\hline 1 & $\begin{array}{l}\text { Subjek membaca soal dengan } \\
\text { tanpa suara sebanyak } 3 \text { kali } \\
\text { sambil melihat teks; } \\
\text { Menceritakan kembali soal } \\
\text { yang telah dibacakan } \\
\text { menggunakan bahasa sendiri; } \\
\text { Menyebutkan yang diketahui } \\
\text { dan ditanyakan; } \\
\text { Menambahkan titik-titik } \\
\text { koordinat yang belum } \\
\text { diketahui pada soal. }\end{array}$ & $\begin{array}{l}\text { Subjek membaca soal dengan } \\
\text { tanpa suara sebanyak } 3 \text { kali } \\
\text { sambil melihat teks; } \\
\text { Menceritakan kembali soal } \\
\text { yang telah dibacakan dengan } \\
\text { menggunakan bahasa sendiri; } \\
\text { Menyebutkan yang diketahui } \\
\text { dan ditanyakan; } \\
\text { Menambahkan titik-titik } \\
\text { koordinat yang belum } \\
\text { diketahui pada soal. }\end{array}$ \\
\hline 2 & $\begin{array}{l}\text { Subjek membaca soal lebih dari } \\
\text { satu kali dengan tanpa suara; } \\
\text { Subjek menyebutkan informasi } \\
\text { yang diketahui dan ditanyakan; } \\
\text { Mengetahui } m_{1}=m_{2} \\
\text { merupakan informasi yang } \\
\text { perlu ditambahkan sehingga } \\
\text { walaupun tidak menentukan } \\
\text { informasi tersebut secara lisan; } \\
\text { Subjek juga menceritakan } \\
\text { kembali soal yang sudah } \\
\text { dibacakan menggunakan } \\
\text { bahasa sendiri. }\end{array}$ & $\begin{array}{l}\text { Subjek membaca soal lebih } \\
\text { dari satu kali dengan tanpa } \\
\text { suara; } \\
\text { Subjek menyebutkan } \\
\text { informasi yang diketahui dan } \\
\text { ditanyakan; } \\
\text { Mengetahui } m_{1} x m_{2}=-1 \\
\text { merupakan informasi yang } \\
\text { perlu ditambahkan walaupun } \\
\text { tidak menyebutkan informasi } \\
\text { tersebut secara lisan; } \\
\text { Subjek juga menceritakan } \\
\text { kembali soal yang sudah } \\
\text { dibacakan dengan bahasa } \\
\text { sendiri. }\end{array}$ \\
\hline
\end{tabular}

Berdasarkan analisis data SP dalam memahami masalah, maka profil memahami masalah SP beserta indikatornya dapat dilihat pada Tabel 10 berikut. 
Tabel 10. Profil memahami masalah SP

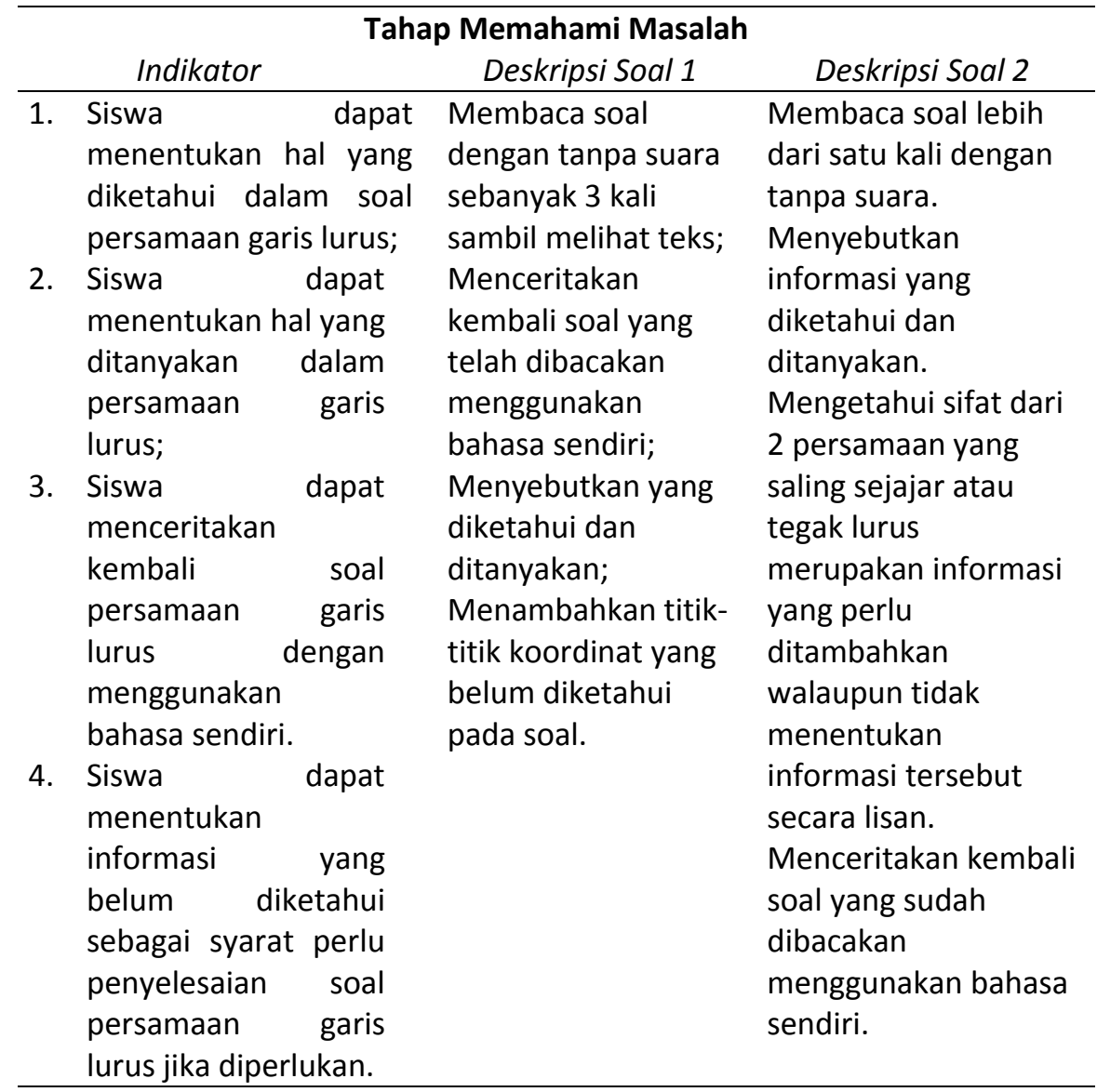

2. Tahap merencanakan pemecahan masalah

Berdasarkan hasil kerja dan wawancara dengan SP, diperoleh deskripsi bagaimana SP membuat rencana pemecahan masalah pada TPMPGL 1 dan TPMPGL 2 pada Tabel 11.

Tabel 11. Deskripsi SP membuat rencana pemecahan masalah

\begin{tabular}{cll}
\hline $\begin{array}{c}\text { Nomor } \\
\text { Soal }\end{array}$ & \multicolumn{1}{c}{ TPMPGL 1 } & \multicolumn{1}{c}{ TPMPGL 2 } \\
\hline & Menentukan rumus mencari & Menentukan rumus mencari \\
& nilai gradient yaitu $m=\frac{\Delta y}{\Delta x}$ dan & nilai gradien yaitu $m=\frac{\Delta y}{\Delta x}$ dan \\
\multirow{2}{*}{1} & rumus $y-y_{1}=m\left(x-x_{1}\right)$ & rumus $y-y_{1}=m\left(x-x_{1}\right)$ \\
& untuk menentukan persamaan & untuk menentukan persamaan \\
& garis; & garis; \\
& Subjek mengatakan banyak & Subjek mengatakan hanya \\
\hline
\end{tabular}




\begin{tabular}{|c|c|c|}
\hline $\begin{array}{c}\text { Nomor } \\
\text { Soal }\end{array}$ & TPMPGL 1 & TPMPGL 2 \\
\hline & $\begin{array}{l}\text { cara penyelesaian akan tetapi } \\
\text { hanya cara tersebut yang } \\
\text { mudah dipahami. }\end{array}$ & $\begin{array}{l}\text { mengetahui cara tersebut } \\
\text { karena sering digunakan untuk } \\
\text { mendapat nilai kemiringan dan } \\
\text { diajarkan oleh gurunya. }\end{array}$ \\
\hline 2 & $\begin{array}{l}\text { Menentukan rumus } \\
y=m x+c \text { dan } \\
\text { menghubungkannya dengan } \\
\text { sifat } m_{1}=m_{2} ; \\
\text { Subjek mengatakan hanya } \\
\text { mempelajari cara tersebut. }\end{array}$ & $\begin{array}{l}\text { Subjek membuat rencana } \\
\text { pemecahan masalah dengan } \\
\text { menentukan rumus } \\
m_{1} x m_{2}=-1, \text { kemudian } \\
\text { menghubungkannya dengan } \\
\text { nilai kemiringan dari tiap-tiap } \\
\text { persamaan garis; } \\
\text { Subjek mengatakan tidak } \\
\text { mengetahui cara yang lain }\end{array}$ \\
\hline
\end{tabular}

Berdasarkan analisis data SP dalam membuat rencana pemecahan masalah maka profil membuat rencana pemecahan masalah SP beserta indikatornya dapat dilihat Tabel 12 berikut.

Tabel 12. Profil membuat rencana pemecahan masalah SP

\begin{tabular}{|c|c|c|}
\hline \multicolumn{3}{|c|}{ Tahap Membuat Rencana Pemecahan Masalah } \\
\hline Indikator & Deskripsi Soal 1 & Deskripsi Soal 2 \\
\hline $\begin{array}{l}\text { Siswa dapat } \\
\text { merencanakan } \\
\text { pemecahan masalah } \\
\text { persamaan garis lurus } \\
\text { sebagai pedoman } \\
\text { dalam penyelesaian } \\
\text { masalah berdasarkan } \\
\text { pemahaman siswa. }\end{array}$ & $\begin{array}{l}\text { Menentukan rumus } \\
\text { mencari nilai gradien } \\
\text { dan rumus untuk } \\
\text { menentukan } \\
\text { persamaan garis; } \\
\text { Subjek mengatakan } \\
\text { banyak cara } \\
\text { penyelesaian akan } \\
\text { tetapi hanya cara } \\
\text { tersebut yang mudah } \\
\text { dipahami. }\end{array}$ & $\begin{array}{l}\text { Mengubah bentuk } \\
\text { persamaan menjadi } \\
\text { bantuk eksplisit dan } \\
\text { menghubungkannya } \\
\text { dengan sifat } 2 \\
\text { persamaan garis yang } \\
\text { saling sejajar atau } \\
\text { tegak lurus; } \\
\text { Subjek mengatakan } \\
\text { hanya mempelajari } \\
\text { cara tersebut. }\end{array}$ \\
\hline
\end{tabular}

3. Tahap melaksanakan rencana pemecahan masalah

Berdasarkan hasil kerja dan wawancara dengan SP, diperoleh deskripsi bagaimana SP melaksanakan rencana pemecahan masalah pada TPMPGL 1 dan TPMPGL 2 pada Tabel 13. 
Tabel 13. Deskripsi SP melaksanakan rencana pemecahan masalah

\begin{tabular}{cll}
\hline $\begin{array}{c}\text { Nomor } \\
\text { Soal }\end{array}$ & \multicolumn{1}{c}{ TPMPGL 1 } & \multicolumn{1}{c}{ TPMPGL 2 } \\
\hline \multirow{4}{*}{1} & Subjek menggunakan rumus & Subjek mencari nilai gradient \\
& $m=\frac{\Delta y}{\Delta x}$ untuk mencari nilai & menggunakan rumus $m=$ \\
& kemiringan dan rumus & $\frac{\Delta y}{\Delta x}$, mencari persamaan garis \\
& $y-y_{1}=m\left(x-x_{1}\right)$ untuk & menggunakan rumus \\
mencari persamaan garis; & $y-y_{1}=m\left(x-x_{1}\right) ;$ \\
& Subjek menggunakan rumus- & Subjek menggunakan rumus- \\
& rumus tersebut dengan tepat. & rumus tersebut secara tepat. \\
\hline \multirow{4}{*}{ Subjek menuliskan yang } & Subjek melaksanakan \\
& diketahui dan ditanya; & rencana pemecahan masalah \\
& Mengubah bentuk persamaan & dengan menuliskan tyang \\
& menjadi $y=m x+c$ untuk & diketahui dan ditanya; \\
& menemukan nilai gradien dan & Mengubah bentuk \\
menggunakan sifat $m_{1}=m_{2}$ & persamaan garis menjadi \\
untuk menemukan nilai $p ;$ & $y=m x+c$ untuk \\
Subjek melakukan kesalahan & menentukan nilai gradient \\
pada saat melakukan & dan menghubungkan dengan \\
penyederhanaan nilai variabel & sifat $m_{1} x m_{2}=-1 ;$ \\
$y$. & Subjek melakukan kesalahan \\
& & pada saat merubah bentuk \\
& & persamaan garis menjadi \\
& & bentuk $y=m x+c$.
\end{tabular}

Berdasarkan analisis data SP dalam melaksanakan rencana pemecahan masalah maka profil melaksanakan rencana pemecahan masalah SP beserta indikatornya dapat dilihat pada Tabel 14 berikut.

Tabel 14. Profil melaksanakan rencana pemecahan masalah SP

\begin{tabular}{lll}
\hline \multicolumn{2}{c}{ Tahap Melaksanakan Rencana Pemecahan Masalah } \\
\multicolumn{1}{c}{ Indikator } & \multicolumn{1}{c}{ Deskripsi Soal 1 } & \multicolumn{1}{c}{ Deskripsi Soal 2 } \\
\hline Siswa menuliskan & Menggunakan rumus & Mengubah bentuk \\
langkah-langkah & untuk mencari nilai & persamaan menjadi \\
penyelesaian & kemiringan dan & kedalam bentuk \\
persamaan garis lurus & mencari persamaan & eksplisit untuk \\
sesuai dengan yang & garis; & menemukan nilai \\
direncanakan; & Subjek menggunakan & gradien kemudian \\
Siswa teliti dalam & rumus-rumus tersebut & menghubungkannya \\
menyelesaikan soal & dengan tepat. & dengan sifat 2 \\
pemecahan & & persamaan garis yang \\
\hline
\end{tabular}




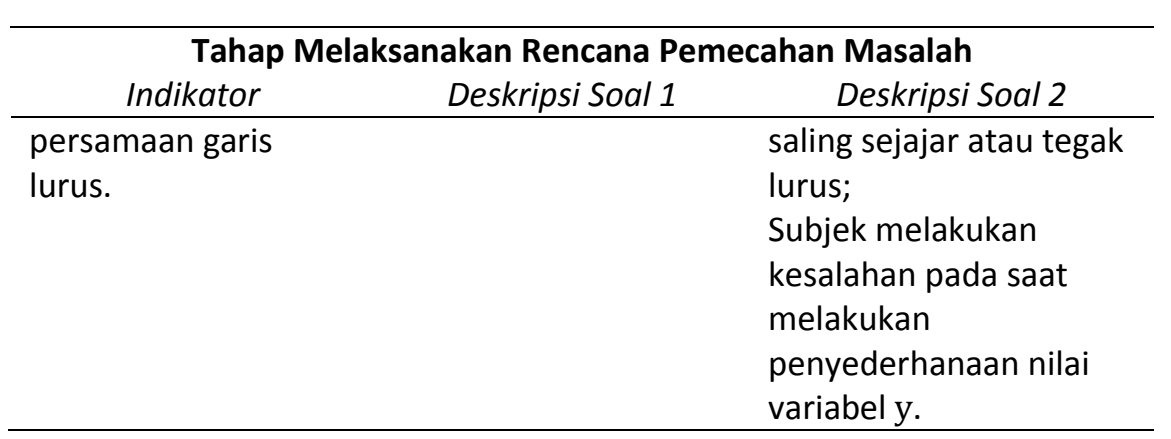

4. Tahap pengecekan kembali hasil pemecahan masalah

Berdasarkan hasil kerja dan wawancara dengan SP, diperoleh deskripsi bagaimana SP mengecek kembali hasil pemecahan masalah pada TPMPGL 1 dan TPMPGL 2 pada Tabel 15.

Tabel 15. Deskripsi SP mengecek kembali hasil pemecahan masalah

\begin{tabular}{|c|c|c|}
\hline $\begin{array}{c}\text { Nomor } \\
\text { Soal }\end{array}$ & TPMPGL 1 & TPMPGL 2 \\
\hline 1 & $\begin{array}{l}\text { Subjek menyatakan kurang } \\
\text { paham pada saat melakukan } \\
\text { operasi aljabar; } \\
\text { Memeriksa kembali hasil } \\
\text { penyelesaian sebanyak } 2 \text { kali }\end{array}$ & $\begin{array}{l}\text { Subjek menyatakan ragu } \\
\text { terhadap hasil penyelesaian; } \\
\text { Memeriksa kembali hasil } \\
\text { penyelesaian sebanyak } 2 \text { kali. }\end{array}$ \\
\hline 2 & $\begin{array}{l}\text { Menyatakan yakin terhadap } \\
\text { hasil penyelesaian; } \\
\text { Memeriksa kembali hasil } \\
\text { penyelesaian sebanyak } 2 \text { kali. }\end{array}$ & $\begin{array}{l}\text { Menyatakan ragu-ragu } \\
\text { terhadap hasil penyelesaian; } \\
\text { Memeriksa kembali hasil } \\
\text { penyelesaian sampai } 4 \text { kali. }\end{array}$ \\
\hline
\end{tabular}

Berdasarkan analisis data SP dalam memeriksa kembali hasil penyelesaian maka profil memeriksa kembali hasil penyelesaian SP beserta indikatornya dapat dilihat pada Tabel 16 berikut.

Tabel 16. Profil memeriksa kembali hasil penyelesaian masalah SP

\begin{tabular}{lll}
\hline \multicolumn{2}{c}{ Tahap Memeriksa Kembali Hasil Penyelesaian } \\
\multicolumn{1}{c}{ Indikator } & \multicolumn{1}{c}{ Deskripsi Soal 1} & \multicolumn{1}{c}{ Deskripsi Soal 1} \\
\hline Siswa melakukan & Subjek menyatakan & Subjek menyatakan yakin \\
pemeriksaan soal & kurang paham pada & terhadap hasil \\
pemecahan masalah & saat melakukan & penyelesaian; \\
persamaan garis lurus & operasi aljabar; & Memeriksa kembali hasil \\
& Memeriksa kembali & penyelesaian minimal 2 \\
& hasil penyelesaian & kali. \\
& sebanyak 2 kali & \\
\hline
\end{tabular}


Berdasarkan hasil analisis TPMPGL 1 dan TPMPGL 2, SL dalam mengidentifikasi masalah dengan membaca soal tanpa suara sebanyak dua kali. Hal ini berbeda dengan hasil penelitian Febrianti dan Masriyah (2016) yang menyebutkan bahwa subjek laki-laki hanya membaca soal satu kali. SL juga dapat menyebutkan yang diketahui dan ditanyakan pada soal dengan suara nyaring. Hal ini terdapat perbedaan dengan hasil penelitian Ramadzani dan Khabibah (2014) yang mengatakan subjek kemampuan sedang yang memahami soal dengan 2 kali membaca untuk menyebutkan yang diketahui dan ditanyakan. Perbedaan tersebut dapat dipahami dengan terjadinya perbedaan kemampuan matematika yang dijadikan subjek penelitian.

Pada tahap membuat rencana pemecahan masalah, SL menentukan rumus yang dianggap tepat untuk mencari nilai gradien dan persamaan garis, kemudian mengerjakannya. Subjek hanya mengetahui satu cara penyelesaian. Dalam melaksanakan rencana pemecahan masalah, SL menggunakan rumus untuk mencari nilai kemiringan dan menentukan persamaan garis. Subjek menggunakan rumus-rumus tersebut dengan tepat namun subjek melakukan kesalahan pada saat menyederhanakan variabel. Penggunaan rumus pada tahap merencanakan pemecahan masalah merupakan salah satu langkah yang dilakukan oleh subjek lakilaki yang mempunyai intuisi antisipatori yang bersifat global. Intuisi antisipatori berawal dari penggunaan kognisi segera dalam memahami soal. Hal ini sesuai hasil penelitian Usodo (2012) yang menemukan bahwa munculnya pemikiran pada subjek S1 menggunakan rumus barisan adalah berusaha dengan mencermati informasi pada teks soal sehingga S1 menggunakan kognisi segera yang digolongkan kedalam intuisi antisipatori. Saat memeriksa kembali hasil penyelesaian, SL melakukan minimal sekali meskipun sudah yakin jawabannya benar.

Berdasarkan hasil analisis TPMPGL 1 dan TPMPGL 2, SP dalam tahap memahami masalah membaca soal tanpa suara sebanyak tiga kali sambil melihat teks, mampu menceritakan kembali soal yang telah dibacakan menggunakan bahasa sendiri, menyebutkan yang diketahui dan ditanyakan dan mampu menceritakan kembali soal yang sudah dibacakan menggunakan bahasa sendiri. Pada tahap membuat rencana pemecahan masalah, subjek menyelesaikan dengan satu cara yang hanya dipahami oleh subjek. Subjek mengubah bentuk persamaan menjadi bentuk eksplisit dan menghubungkannya dengan sifat dua persamaan garis yang saling sejajar atau tegak lurus. Dalam melaksanakan rencana pemecahan masalah, subjek menggunakan rumus untuk mencari nilai kemiringan dan mencari persamaan garis. Subjek menggunakan rumus-rumus tersebut 
dengan tepat dan subjek melakukan kesalahan pada saat melakukan penyederhanaan nilai variabel $y$. Saat memeriksa kembali hasil penyelesaian subjek menyatakan kurang paham pada saat melakukan operasi aljabar dan memeriksa kembali hasil penyelesaian sebanyak dua kali.

Berdasarkan profil kemampuan pemecahan masalah siswa berdasarkan jenis kelamin, guru matematika dapat merancang pembelajaran yang dapat memfasilitasi siswa laki-laki dan perempuan dengan kemampuan matematika tinggi dalam menyelesaikan masalah matematika, mengantisipasi kesalahan yang dilakukan, dan mengembangkan kemampuan pemecahan masalah matematika. Misalnya, siswa diberikan penguatan saat guru memberikan materi prasyarat di awal pembelajaran terkait kesalahan siswa dalam menggunakan konsep atau rumus. Guru juga bisa memanfaatkan scaffolding untuk mendukung siswa menemukan alternatif jawaban yang berbeda dalam pemecahan masalah. Profil pemecahan masalah siswa dengan kemampuan matematika rendah dan sedang dalam memecahkan masalah PGL perlu diteliti lebih lanjut untuk mendapatkan gambaran komprehensif terkait bagaimana siswa menyelesaikan masalah secara umum dan pada materi PGL secara khusus.

\section{Simpulan}

Hasil penelitian menunjukkan bahwa tidak ada perbedaan signifikan profil subjek laki-laki dan perempuan dengan kemampuan matematika tinggi dalam memecahkan masalah PGL. Subjek laki-laki dan perempuan mengidentifikasi masalah dengan membaca berkali-kali soal tanpa suara dan mampu menceritakan kembali soal yang telah dibacakan menggunakan bahasa sendiri sambil melihat teks. Pada tahap merencanakan penyelesaian masalah, subjek laki-laki dan perempuan sudah dapat menuliskan apa yang diketahui ditanya dan mengubah bentuk soal cerita menjadi model matematika. Pada tahap melaksanakan rencana penyelesaian masalah, subjek laki-laki dan perempuan masih keliru dalam menggunakan rumus atau konsep matematika. Dan pada tahap pengecekan kembali, subjek laki-laki dan perempuan melakukan pengecekan kembali terhadap hasil penyelesaian. Perbedaan terletak pada frekuensi siswa membaca ulang soal pada tahap memahami masalah dan memeriksa kembali hasil penyelesaian masalah.

\section{Daftar Pustaka}

Aminah, E. \& Wulandari, S. (2011). Perbedaan jenis kelamin terhadap kemampuan siswa dalam mata pelajaran matematika (Studi Kasus di Sekolah Dasar). SOCIOSCIENTIA Jurnal IImu-IImu Sosial, 3 (1), 19-20. 
Azhari, B. (2011). Peningkatan kemampuan pemecahan masalah matematika melalui creative problem solving pada mahasiswa pendidikan matematika, Fakultas Tarbiyah dan Keguruan, UIN Ar-Raniry. Pusat Penelitian dan Penerbitan, Lembaga Penelitian dan Pengabdian Kepada Masyarakat. UIN Ar-Raniry.

Febrianti, R. \& Masriyah. (2016). Profil Pemecahan Masalah Matematika Siswa dalam Menyelesaikan Soal Cerita ditinjau dari Perbedaan Jenis Kelamin. MATHEdunesa: Jurnal IImiah Pendidikan Matematika, 2(5), 8189.

Hudoyo \& Sutawijaya. (1998). Pendidikan matematika I, Jakarta: Dirjen Dikti Depdiknas.

Kemdiknas. (2006). Permendiknas nomor 22 tahun 2006 tentang standar Isi untuk satuan pendidikan dasar dan menengah.

Krulik, S. \& Rudnik, J. A. (1996). The new source book teaching reasioning and problem solving in junior and senior hig school. Massachusets: Allyn \& Bacon.

Mullis, I. V., Martin, M. O., Foy, P., \& Arora, A. (2012). TIMSS 2011 international results in mathematics. Amsterdam: International Association for the Evaluation of Educational Achievement.

OECD. (2014). PISA 2012 results in focus: What 15 year olds know and what they can do with what they know. Paris: OECD Publishing.

OECD. (2016). PISA 2015 results excellence and equity in education (Volume I). Paris: OECD Publishing.

Polya, G. (1973). How to solve It princeton, New Jersey: University Press.

Ramadzani, A. R. \& Khabibah, S. (2014). Profil peserta didik SMP kelas VII dalam menyelesaikan soal cerita materi pecahan ditinjau dari kemampuan matematika. MATHEdunesa: Jurnal IImiah Pendidikan Matematika, 3( 3), 195-201.

Sugiyono. (2013). Metode penelitian kuantitatif kualitatif dan R\&D, Bandung: Alfabeta.

Tanjungsari, R. D., Soedjoko, E., \& Mashuri. (2012). Diagnosis kesulitan belajar matematika SMP pada materi persamaan garis lurus. UNNES Journal of Mathematics Education, 1(1), 52-57.

Usodo, B. (2012). Karakteristik intuisi siswa SMA dalam memecahkan Masalah matematika ditinjau dari kemampuan matematika dan perbedaan gender. Aksioma: Jurnal Pendidikan Matematika, 1(1), 1-14.

Zaif, A., Sunardi, \& Diah, N. (2013). Penerapan pembelajaran pemecahan masalah model Polya untuk menyelesaikan soal-soal pemecahan masalah pada siswa kelas IX SMP Negeri 1 Jember semester ganjil tahun ajaran 2012/2013, Pancaran Pendidikan, 2(1), 119-132. 